\title{
Visions of Brotherhood. A Comparative Analysis of Direct Democracy in Ancient and Modern Greece
}

\author{
Manussos MarangUdAKIS \\ Associate Professor, Department of Sociology, University of Aegean \\ m.marangudakis@soc.aegean.gr
}

Recibido: 21-10-2015

Aceptado: 20-06-2016

\begin{abstract}
Collective "memories" of the original democracy of classical Athens have inspired the formation of the direct-democracy, "Syntagma Square" movement. The movement, a reaction to the ongoing social crisis in Greece, challenges the legitimacy of the liberal, representative, democracy accusing the "memorandum party system" for immoral contact and treasonous collaboration with Greece's foreign debtors. Taking this development as an opportunity to examine in situ a modern version of "direct democracy" and the cognitive patterns that animate it, the essay compares ancient and current democratic processes and reflects on their ontological and cosmological presuppositions. Employing the Weberian concept of "acosmistic brotherhood" the essay analytically explores and compares the two democratic instances and reflects on the foundations of a stable democratic regime.

Key words: direct democracy; acosmistic love; communitas; Greek crisis; Greek Indignados; Syntagma square movement; Weber.

\section{Visions of Brotherhood. Un análisis comparativo de la democracia directa en la Grecia antigua y moderna}

\begin{abstract}
Resumen
La memoria colectiva de la democracia de la Antigua Grecia ha sido la inspiradora de los movimientos de democracia directa de la plaza Sintagma. Estos movimientos, entendidos como una respuesta a la creciente crisis en Grecia, cuestionan la legitimidad de la democracia liberal representativa, a la que se acusa de "memorándum del sistema de partidos" debido a su relación inmoral y alevosa con los acreedores extranjeros de Grecia. Tomando estos hechos como una oportunidad para examinar in situ una versión moderna de la democracia directa, este trabajo compara los procesos democráticos antiguos y modernos y reflexiona sobre sus presupuestos ontológicos y cosmológicos. A partir del concepto weberiano de "Liebesakosmismus", el ensayo explora analíticamente y compara los dos momentos democráticos y reflexiona sobre las bases de un régimen democrático estable.
\end{abstract}

Palabras clave: Democracia directa; amor acosmístico; communitas; crisis griega; indignados griegos, movimiento Plaza Syntagma; Weber.

\section{Referencia normalizada}

Marangudakis, M. (2016): "Visions of Brotherhood. A Comparative Analysis of Direct Democracy in Ancient and Modern Greece", Política y Sociedad, 53 (3), pp. 773-793.

Sumario: Introduction. 1. The political model of classical Athens. 2. Direct Democracy in Athens today. 3. The Greek republican; modern and ancient. 4. References. 


\section{Introduction}

The ongoing economic crisis that erupted in Greece in 2009, and that by 2011 had turned into a legitimation crisis of the political system, gave rise to the "Syntagma Square"

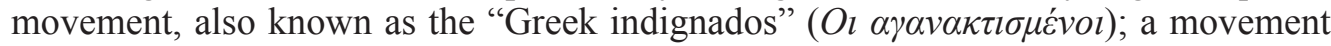
that challenged parliamentary-representative democracy, promulgating, at the same time, a return to "direct democracy" which they traced back to classical Athens and the celebrated rule of the people. The presence of this social movement, notwithstanding its short-lived existence gave us the opportunity to examine two interrelated issues: has the ancient direct democracy, as an institution and practice, anything to do with its modern proponents? And if so, what can we learn about us moderns from such comparison?

In the following pages I will present some aspects of the classical Athenian democracy in conjunction with some recent studies of the contemporary Greek movement for the restoration of republican, direct-democracy, practices. Following a Weberian model of analysis, I will reflect on the two anthropological types of citizen and their ability to sustain a democratic regime.

\section{The political model of classical Athens}

The presence and function of direct democracy in ancient Athens is related to (a) the actual presence of direct participation; (b) the process of selecting magistrates by lot; and (c) whether Athenian democracy was concerned with "social justice", or to be more precise, concerned with the redistribution of wealth for the benefit of the lower classes. ${ }^{1}$

First, let us examine the issue concerning of actual, tangible, presence of the direct participation of citizens in decision making, vis-à-vis the process of representative democratic institutions. In this case we need to contrast the regular physical presence of citizens in the meeting-place of decision-taking, as well as the free expression of opinion of those present, vis-à-vis the consultation of the few elected representatives. In the first case, citizens directly chose and vote for the issue at stake, following a few and simple rules mostly concerning time restrictions for the speakers. In the second case, the citizens authorize a small number of fellow-citizens to take decisions on their behalf, with term of office (usually four years) following strictly pre-determined rules of discussion and rules for decision-taking. As the argument goes, the system of representation is prone to perversion and corruption. Even in the absence of such inefficiencies, the representative system encourages the development of a political elite (or cast) which cares more about their own interests rather than the interests of those who they represent. Let us examine in detail the Athenian system.

For starters, the Ecclesia of demos in classical Athens, i.e. the institutionalized assembly of citizens, was neither gathered voluntarily, nor very often. It was assembled

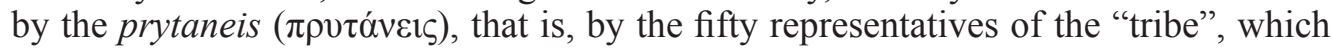

${ }^{1}$ The following is primarily based on the analysis of the Athenian democracy by Kyrtatas (2014), and Hansen (1991). 
was in charge of the institution, every month (the Athenian demos was divided in ten municipals "tribes", each one represented by fifty bouleutes), according to strict rules, and no more than forty times a year. Then, during the Ecclesia sessions, everyone had, in principle, the right to speak, but the political ethics of the day, the necessary preparation and the cruelty of the crowd, did not allow ordinary citizens to discuss any matter they wished to (Adkins, 1972: 250-267). Those who gathered at the Ecclesia did not have the right to suggest any possible topic of discussion and debate. The drafting of the agenda was strictly the prerogative of the fifty prytaneis. More important, the various issues were not suggested by the prytaneis openly and unconditionally. They were already discussed extensively in the Boule (Bov $\lambda$ ) of the five hundred which codified the possible decisions and choices in certain drafts, the probouleumata $(\pi \rho \circ \beta$ ßov $\lambda \varepsilon v \mu \alpha \tau \alpha)$. The Ecclesia itself was commending and discussing on the matters already on prearranged proposals. The most the Ecclesia could do was to ask the Boule to draft laws and decisions and to propose amendments to those presented to them. Last, and probably more important, not all citizens were assembled in the Ecclesia; instead, only $1 / 5$ or even $1 / 10$ of the eligible citizens were present at any time depending on the importance of the subject (Hansen, 1991: 130-132). This percentage corresponds to roughly six thousand citizens and there were measures that denied entry to a higher participation. But there were also measures and efforts to guarantee that the number of participants will remain high and thus the process legitimated; but functional as well. Thus, if we take into account that the total number of citizens in classical Athens was roughly thirty to fifty thousand men, the formal permission of only up to six thousand participants in the Ecclesia made the institution a representational sample of the will of the Athenian citizens, even though it was not representative as such. In any case, the system was certainly not "direct". A predetermined number of citizens were taking decisions in the name of an unspecified and varied number of citizens. To be precise, it ratified or amended decisions that were beforehand elaborated by five hundred representatives, the prytaneis, with a term of one year. Thus, the Athenian democracy resembled more a current representative democracy rather than the spontaneous gatherings in the Agora.

In other words, in the heart of the Athenian political system was the Boule of the five hundred. Without it, the Ecclesia could not be assembled, it could not decide, and it could not implement its decisions. Its significance becomes obvious if we take into account the fact that it was assembled daily, during all the working days of the year ( 275 days in all). It was the body that followed all the important matters of the city continuously and closely. Even then, a body politic of five hundred members that functions daily is not usual in history. Notwithstanding the experience of its members, such a number makes discussion, debates, and consensus difficult, to say the least. The prytaneis were not professional politicians and had no expertise of dealing with or of framing the issues of the day. Most of them probably were not even taking the floor. It is reasonable to presume that the debates were taking place between seasoned prytaneis that happened to be in office for more than one term. Most of them were just listening to the elaborated arguments of the few experienced ones, who were taking the floor, before voting for or against the proposals. The painful daily presence of those five hundred people could only be explained by one presumption: the large number of 
representatives was legitimizing the procedures of the Boule as reflecting the will of the Athenian people.

The character of the Boule is revealed by the process of its formation. It was the representative body of the ten virtual "tribes" that Clisthenes had divided the Athenian citizens in. But their selection was based to a much larger extent on the 139 municipalities (demos) consisted of small or larger geographical units. Every demos submitted a number of candidates out of which a certain number was chosen by lot. Thus, every demos was actually represented in the Boule, and so every geographical, demographic and class aspect of the Athenian body politic. The representation of the Athenians was complete. As it has been calculated, the draw was not a crucial aspect of the process. In fact, it was regulating the sequence of the office rather than the service in the office itself. One-third of all Athenian citizens above thirty years of age had served in the Boule at least once in their lifetime during the twenty-five years before the Peloponnesian war, and no-one could be chosen for more than two times in their lifetime.

This means that the Boule was quite a bureaucratic institution. It was mostly a political institution which approved motions and formulated proposals. Thus it was guaranteed that the proposals presented in front of the Ecclesia were authoritative and as such were accepted. It was a credible body because the number of its members was large enough to symbolize the Athenian Demos as a whole.

The second major and contested issue is the selection of the magistrates not by vote but choosing by lot. Interestingly enough, the latter was considered to be the essence of democracy even by contemporaries (e.g., Aristotle, Politica, 1294b 8; fc. $1317 \mathrm{~b} 21$ ) in contrast to voting in office that was considered an oligarchic feature. Lot, unconceivable in modern democracies, verified the equality of all citizens as it did not allow clientelism and favoritism. It nullified electoral campaigns as well as the privilege of wealth, eloquence or charisma. Democracy was run by ordinary citizens that represented the will of the whole body of citizens.

Yet, the assertion that sortition suits democracy was elaborated strictly by its enemies, i.e. Socrates, Plato, and Aristotle. In fact, these reasonable arguments are challenged by the historical records of the time. The Athenian democracy itself was rationalizing the issue is quite different way. If democracy itself was considering sortition to be the essence of the democratic ideal, it would have practice it in the process of choosing the most important magistrates, the ones that were commanding the city-state. Yet, sortition concerned 1100 magistrates (the 500 prytaneis of the Boule, plus six hundred others of various responsibilities) who were chosen to serve for only one year, without any right to be reelected in the same post, except of the prytaneis who could be drafted for two terms in office. Most of the one hundred supreme magistrates, amongst them the generals of the army, the tutors of the youth, the finance magistrates, the person responsible for the water supply, and the citizens responsible for the religious ceremonies, were elected not by lot but by vote; and the most important ones had the right to be reelected over and over again.

The basic democratic principle was that of the majoritarian rule (in spite of its potential drawbacks) and thus the counting of the votes. Sortition, in contrast, was not a 
democratic conception. In the mind of the citizens it was following aristocratic principles which were applied in religious practices or oracles and soothsayers. Allotment, in the mind of an Athenian, was not guaranteeing egalitarianism and representation, but divine favoritism and praise. It was considered to be preferred for offices of no great importance, and its practice did not intent to promote the office, but to downgrade it. When there was any doubt on responsibilities, power was given to the electives, not the draftees.

In this context, it is interesting to examine the way the bouleutes were chosen. The need to find every year five hundred citizens available for daily meetings suggests that most local municipalities ( $\delta \dot{\eta} \mu \mathrm{o})$ suggested as candidates very few citizens. Thus, it is perfectly possible that allotment was not important but only for choosing the bouleutes and their replacements (one to two hundred citizens in all). As for the rest of the magistrates, they were usually volunteers who had the time and the motivation to fill the office. Drafting was a way to assure that the number of the available citizens was larger than the number of offices, making selection a swift process.

The Athenians were aware that governing the city was a very serious business to be left to chance or to gods. Even for the draftees there was a system of pre-selection to exclude the ineligible. Allotment was more an ideology rather than an unqualified practice. In principle it was proclaiming all citizens to be aristocrats by nature and by culture, and it was this principle that legitimized the regime.

Last, the issue of distributive justice. The concept is usually considered as synonymous to social justice not through economic mechanisms, but through political decisions. In fact, the term 'democracy' becomes coterminous to socialism under the presence of politically induced redistribution. In this argument, political democracy is the means to achieve economic equality. But how did the Athenians perceive the two? And how did they deal with their potential interconnection? We will begin with the margins that the democratic regime had to intervene in property matters.

According to its principles, the Athenian democracy was not restricted by any means to make any decisions it wished to. It had the capacity to give the citizen's right to foreigners; the right to free slaves, and to issue fines and special contributions; to declare war and to make peace. Yet, the Athenians never touched on economic redistribution. The republic demanded its wealthiest citizens to contribute in matters of war, celebrations, and public festivals, but these were acknowledged to be special occasions. The wealthy were accepted as such: politically equal, yet economically superior to the rest. There was no tax policy whatsoever in Athens targeting the Athenians. Taxation was enforced on other city-states that through the establishment of the Delian League became the vassals of Athens. Looting, exploitation of the metics and slave labor (mainly in the silver mines of Attica), were the means to fund the Athenian budget. The Athenian democracy considered its duty to protect the rich as a matter of principle as well as of interest. When members of the judiciary $\left(H \lambda \lambda_{1} i^{\alpha} \alpha\right)$ were undertaking their duties, they were giving the oath of not cancelling individual debts neither to redistribute Athenian lands (Xenophon, Hellinika, 1.7.12).

As Demosthenes argued, in the mid fourth century when public finances were in miserable conditions, Athens could be optimistic. "There is enough money" he 
said, gathered in the hands of a few wealthy fellow citizens". The matter, though, he continues, that demanded some thought was the demos should not try to take possession of it before the time was right. Even rumors of such an intention before the threat was clearly visible would lead the owners of this wealth to hide their possessions. Thus, any call for special contribution would have poor results. Only the moment the enemy would be at the gates, in an effort to save at least part of their property, the rich will freely donate their wealth to the city (Demosthenes, 24.149).

The equality that the Athenian democracy promulgated, and to a large extent achieved, was political, not economic (Demosthenes 14.24-26.). On the other hand, the Athenian democracy did have an economic dimension, albeit an apophatic one: It was not allowing the wealthy to confiscate or appropriate the land of the less wealthy or even the poor citizens. And it was certainly not allowing the enslavement of free citizens due to debts. In a nutshell, the Athenian democracy was not radical, but conservative, aiming to preserve the status quo and not to topple it.

Thus, the Athenian democracy was neither direct nor redistributive. Even though many institutional posts were staffed by lot, the Athenians probably would have not considered sortition as the quintessential feature of the regime. The Athenian democracy cared for two basic principles: to make decisions according to the will of the citizenry and to be effective - something that was accomplished for most of the $5^{\text {th }}$ century. If there were a fatal weakness in the system, this was its inability to accept the expansion of the right to Athenian citizenship beyond the Attica borders. In other words, its weakness was not "direct democracy" but "ethnic democracy." But this is another issue altogether.

Accurate and complete representation was the essence of political participation, and this was the masterpiece of the Cleisthenian reforms. He re-organized the city in municipalities and tribes ( $\varphi v \lambda \alpha i$ ) in such a way that even a tenth of the citizens, and only one tribe, could represent the whole city. Thus, the large number of citizens (thirty to fifty thousand men) could not become an obstacle to decision-taking process, or the implementation of the laws based on the majority principle.

Yet, there is an aspect of the Athenian democracy that was truly in line with the principle of direct democracy: I refer to the 139 local municipalities the Athenian people were divided in. These municipalities were not reflecting any virtual aspect of the citizenry as the ten tribes were. ${ }^{2}$ On the contrary, local municipalities were the living and breathing space of every Athenian; his neighborhood. One of the very few things that we know of them is that their assemblies were summoned very often and these assemblies were responsible of all things local. Also, all (male) citizens were obliged to be present and participate in the process. What was required of them was "to speak candidly at your risk"; ${ }^{3}$ it was called parrhesia. ${ }^{4}$ Parrhesia was the corner-stone

${ }^{2}$ These "tribes" were an intentional mixture of urban and rural populations, of mountain and valley and seafaring, an accurate microcosmos reflecting the Athenian macrocosmos

${ }^{3}$ Foucault (2001: 15-20)

${ }^{4}$ From "pan" (i.e. "comprehensively") and "rrhese" (i.e. "statement"). 
of Athenian democracy, the "psychological incubator" of civic virtue, in contrast to rhetoria that was associated with fakeness and the corruption of the regime (Aristotle, Nicomachean Ethics [Book IV, 1124b28]). Based on parrhesia, the municipalities were the cells of the Athenian democracy, vivid and vibrant schools of the democratic citizenry who voiced his concerns in public (even against popular opinion), before some of them were brought to the attention of the bouleutes and the Ecclesia (Wallace, 2002).

In all, it would be safe to suggest that the classical Athenian regime was a combination of ("low") direct and ("high") representative democracy with its most important concern being the legitimation of the decision making process as reflecting the sincere and unmediated "people's will".

Unfortunately, later on the representative aspect of the regime was downplayed at the expense of the direct one. In a famous passage Aristotle declared: "It is accepted as democratic when public offices are allocated by lot; and as oligarchic when they are filled by election" (Aristotle, Politics 4.1294be). Thus, "who wishes to speak" ( $\tau 1 \zeta$

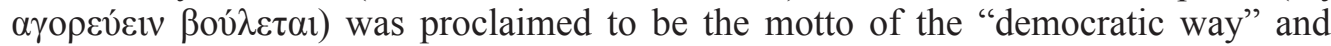
this is how it came to be taught in the modern Greek curriculum. Wrongly, it became the symbol of the original and pure form of Democracy, and as the argument unfolds, modern, representative, democracy is a "pragmatic compromise", a necessity rather than a principle, due to the large number of citizens a modern state is comprised of.

\section{Direct Democracy in Athens today}

In Greece, this "compromise" has been challenged by a long list of leftist social groups and movements that consider representative democracy to be anything but democratic. Rather, they consider it to be a form of oligarchy paying only lip service to genuine democracy. When depression and the accompanying social crisis hit Greece in 2009, six years ago, disaffection for the government and politics-as-usual (the Metapoliteusis era, 1974-2010) joined forces with this, hitherto, marginal promulgation, to form the so-called "Syntagma Square movement". The latter combined resistance to the austerity measures enforced by the "troika", display of national pride, and a challenge to the parliamentary regime as corrupt.

Starting with the latter, many activists in the Syntagma Square movement accused the existing political regime of being a cleptocratic oligarchy, violating citizens' rights and curtailing its constitutional power. Thus protestors' slogans linked the Square movement to the Polytechnic uprising (November 17, 1973) against the Dictatorship that ruled Greece for seven years (1967-1974) as the slogan "Bread, Education, Liberty: The junta did not end in 1973" (sic) emphasized. As the slogan implied, it dismissed the whole post-dictatorship era, even though the latter has been the longest period of democratic stability in Greece's modern history. In the narratives of the Square

5 "Troika": the representatives of the International Monetary Fund, the Central European Bank and the European Commission 
movement 'democracy' became a reference detached from parliamentary institutions. As such, "democracy" gradually became a floating signifier to be directly related to "memories" of the original, ancient, condition.

A second popular slogan, voiced at the same time, gave the tone of how genuine democracy was perceived: "Let it burn, let it burn, the brothel, the Parliament". The Parliament, the symbol and the institution that stands for representative democracy, in the eyes of the Syntagma Square movement was delegitimized. In an intentional effort to replace it the advocates of the movement brought to life in Syntagma Square itself a deliberate experiment of practicing direct democracy. In the lower part of the Square (the upper part was occupied by nationalist hard-liners inspired by equally intense hate for the Parliament), multiple working groups were established to support and sustain ad hoc collectivities made of various social groups mobilized for the occasion (e.g., a nursery, a food and beverage rationing group, a media group, a cleaning team, an artistic team, a web information team). The working groups were set up to operate horizontally, according to the principles of direct democracy. The reason d'être behind these actions was meetings and discussions about the economic condition of Greece and the possibility of alternative economic policies, thus allowing citizens to voice their opinion and act as if direct democracy mattered. This process and participatory ethos guided the proceedings of popular assemblies, the main decision-making body of the movement.

Below, I cite some minutes of the first open assembly held at Syntagma Square on May 25 2011, which are quite representative of the mood prevalent among the protesters:

Any politician, who commits injustices, anyone not respecting popular demands, must go to their home or to prison. Their democracy can guarantee neither equality nor justice.

We should not be satisfied with being consumers or customers, we should be satisfied with being good and responsible citizens.

We should look at this issue - of our robbed lives - globally. We should connect with anything similar happening across the world. It is not only the politicians who are to blame, it is all of us with our individualistic behaviour.

We must continue with consistency the revolts of the Arabic world, to lift ourselves above homelands and nations. We must start formulating demands; for politics to change, for the government to go - let's co-shape our own proposals.

The health system collapses; there are no more disposable materials; people in hospitals are in danger; they [politicians] are abandoning us.

Democracy began from here, in Athens. Politics is not something bad. To improve it, let's take it back into our own hands.

The problems are common and they are what unites us. We should not allow [political] banners, or whatever chooses to divide us.

The Spanish people gave us the idea and the cue. We must co-ordinate with the rest of the debt-ridden South, we must mobilize. The Spanish people have shown us the way. 
They slander civil servants, teachers, lecturers, doctors. Justice is not the 500 euro [salaries]. They deprive us of dignity.

Greece is at the edge of the cliff and the money of the country is already abroad. They robbed us, and continue to do so. ${ }^{2}$

And this is the resolution by one of the early open assemblies at Syntagma Square:

For a long time now, decisions have been made for us, without us. We are workers, unemployed, pensioners, youth who came to Syntagma to struggle for our lives and our futures.

We are here because we know that the solution to our problems can only come from us.

We invite all Athenians, the workers, the unemployed and the youth to Syntagma, and the entire society to fill up the Squares and to take life into their hands.

There, in the Squares, we shall co-shape all our demands.

We call all workers who will be striking in the coming period to end up and remain at Syntagma.

We will not leave the Squares before those who led us here leave: Governments, the Troika, Banks, Memorandums and everyone who exploits us.

We say that the debt is not ours.

DIRECT DEMOCRACY NOW!

EQUALITY - JUSTICE - DIGNITY!

The only defeated struggle is the one that was never fought!

Every evening at nine o'clock a general assembly was held (Tsaliki, 2012). The selection of speakers was random. Numbers were allocated randomly to participants and lots were drawn to determine the order of speakers on the podium (Leontidou, 2012). Every day, approximately a hundred people expressed their opinions.

The encampment was not an isolated incident of direct democracy. Instead, its activists were, or became, connected to a broader network of neighborhood activists who were also organized horizontally to "take into their own hands" the public sphere and issues, aiming to a radical transformation of political/social relations. Therefore, links were established with other actors (e.g. neighborhood assemblies) to further mobilizations and contestation.

The republican network, that was spread out to the Athenian neighborhoods and beyond, but always keeping the Syntagma Square as its charismatic center, constructed an alternative public realm in which people interacted, debated, were informed and expressed feelings. Next to articulating opinions, the participants also shared feelings of anger, confusion and anxiety. Social interaction among strangers was a common pattern. Since in the Greek context problems like poverty, unemployment and private debt were experienced by numerous and diverse social groups, they were openly discussed and debated.

Nevertheless, the direct-democracy movement differed from the Spanish Indignados and the American Occupy movements in regard to inclusiveness. In the latter two movements, political activism was coupled with an aspiration to create spaces open to diversity (Asen, 2000). The Syntagma Square was different; it was a site of confrontation of a highly polarized part of the society against the government. Demonstrators did 
not simply voice their opposition to austerity policies. They struggled to bring down the government and repeal the memorandum. For protestors, the movement's outcome would determine their personal lives and the country's future. Hence, priority was given to immediate political confrontation with the government. In this context, heterogeneity of opinions was not allowed but only within the anti-memorandum bloc (e.g. to stay in or leave the euro zone). People who were ambivalent about the memorandum were not welcomed and different voices were silenced in a quite uncivil manner (Tsaliki, ibid.).

But as was mentioned earlier, hatred for the government, the memorandum, and its supporters was not all. The movement was not just a protest one. Rather, it deliberately moved on to materialize a new communitas and with it a renewal of the true, direct democracy. A series of interviews with members of the Syntagma Square movement that were taken in situ during its high days confirm the strong egalitarian temperament of the participation. ${ }^{6}$ Time and again the interviewees expressed their commitment to form new social structures and, though these, new political structures based on trust, cooperation and collective values. Many of the participants were fully absorbed by the task at hand organizing events, participating in debates, offering their services and expertise, and mobilizing friends and colleagues to the cause: to create ex nihilo an alternative, functional, political and social structure to combat all the ills of democracyas-usual.

A 30-year-old employee in a software company captures the spirit of the movement with these words: "At the beginning there was a great sense of being alive... of being in the company of people I had never seen before, of expressing your frustration and your worries and your dream for true politics coming from the people themselves without in-betweens... I spend my daytime at work and then at the Square until late at night... I was there, present, body and soul... it did not matter so much what the issue was or who spoke, what matter is the fact that we talk as citizens"

Another participant, an older woman in her forties stated: "My husband was fired after ten years of working as a mechanic. I was enraged... still am. A friend of mine told me about the happenings at the Syntagma Square and went with her, to check it out. I felt good, so many others just like me. I want to be proud again, of myself, my family, my country. There were no strangers there. We are all equals, discovering each other, other citizens... we are all citizens after all, but we did not exist, not before the crisis... I felt like a full, complete, citizen"

A third one, a 33-year-old member of the informal network of anti-authoritarian anarchic movement said: "I feel so vindicated that my struggle has become the struggle of so many. I do not fool myself thinking that these people have come to join us in our struggle against authoritarianism, but it feels good to know that there is not much that divide us... it felt good, people who are concerned with pride, and autonomy, and community, and not with consumer goods... yes, a year before was exactly what

${ }^{6}$ Marangudakis, M. From Salvation to Purgatory: Cultural Codes and Moral Orders in Greece. Propompos: Athens (forthcoming); Marangudakis, M. Kostas Rontos and Maria Xenitidou (2013) "State Crisis and Civil Consciousness in Greece", GreeSE: Hellenic Observatory Papers on Greece and Southeast Europe, 77. 
they cared for, and probably this is where they will return to after the crisis... but you cannot be sure, they just might become communitarians, perhaps they have become communitarians!"

A physician who volunteered to help running a social pharmacy stated: "To offer my help is not an extra-ordinary activity. It is the activity that defines me as a citizen. I have learned so much the last weeks about myself and about my fellow citizens. This is how we should build our new society, a society of providing for the have-nots, a society of people who run their own affairs without mediations, without professional politicians. I know this might sound like fantasy, but we will all come out of it a bit different, a bit more communal. It's exhilarating... feeling alive, part of the collectivity, offering to the people".

A 37-year-old teacher in a public crèche reflected: "I became involved in politics in the late 1990s during the student movement. We were beaten so much by the police those days... and slowly I realized that the solution is in the community... is the community. I have struggled for the rights of the poor to voice their discontent, and the rights of the immigrants to be safe wherever they are... When I look around me I see fellow citizens, world-citizens, all looking for common answers to common concerns."

There was true commitment expressed in lengthy and arduous tasks (e.g., preparative committees, chairing the proceedings, passing resolutions, organizing the events for the following days, contacting neighborhood councils, etc). People had to make time at the expense of their jobs (for those who still had one), family, etc. For a few months the experiment went on. Alas, the Syntagma Square movement faded away a few months later falling victim of its own shortcomings. Lack of institutionalization of the social networks that participated in the movement, internal strains and tensions, emotional fatigue, the infiltration of the movement by lumpen elements that degraded the occasion symbolically as well as aesthetically, were all crucial to its downfall. And then, wider, political, developments took over the public concern resulting in the absorption of movement by the anti-memorandum parties, mainly the radical left party SYRIZA.

What was important for them, and for us, was that these people were not satisfied by expressing their rage; rather, they wished to turn it to something productive, and thus they combined rage with a wish to renew civic life. What kind of mentality urged them to do so? Their efforts and actions became the way some interesting cultural patterns, social representations, and moral imperatives of the participants to surface. I turn to the analysis of these patterns comparing them to the virtuous citizen of classical Athens.

How compatible is this social movement and the ethical orientations of its members with the virtuous communal engagement that we encounter in classical Athens? I will endeavor to delineate some anthropological features of the rank and file of the latter, following the Weberian typology, before attempting to compare them with those of classical, democratic, Athens. This is a highly speculative comparison, and I take it as a heuristic tool to consider the potential of the direct-democracy movement to renew democracy in contemporary Greece. 


\section{The Greek republican; modern and ancient}

There should be little doubt that the novel cultural element that the crisis brought forward, and actually precipitated, is direct democracy (republicanism henceforth), both as a discourse and, through political action, as a constellation of social movements. The Syntagma Square movement, with its local branches, was not a demonstration of frustrated citizens who voice their concerns and worries, but a deliberate effort to rebuilt republican social structures. "Direct democracy", the main and key exclamation of the social movements' mobilization, was virtually non-existent twenty years ago and hardly noticeable a decade ago. In the Metapoliteusis era "social movements", such as the peace or the feminist movements, were practically party subdivisions following party lines. Not anymore; the Syntagma Square movement and its branches have not only emancipated themselves from party straightjackets, but they elaborate new discourses that emerged out of the Metapoliteusis democratic code, with some crucial mutations.

First and foremost is the rejection of the party-mobilization, charismatic-leader, pattern that dominated the political landscape in the ante-crisis era; no submission to the leader, and no material reward coming out of such submission was accepted. Second, it is the rejection of the national community as a community of blood. Instead, the meaning and symbolism of "people" expanded to denote the universal community of those who suffer and struggle against injustice; the strong pro-immigrants movement that was developed in the last decade was culminated and found clear political expression in the Syntagma Square movement. Third, it is the horizontal and egalitarian character of voluntary groups that emerged out of the more general social movements: the permanent occupation of various public buildings in the name of self-management, group initiatives for the rejuvenation of urban sites, cultural happenings, co-operatives, and anti-systemic social media belong to this genre. They form a new pattern of social action and of social structures, and a new codification of constitutive goods, and as such they constitute constituent elements of a new social ethics.

The contemporary republican discourse suggests a certain detachment from routine, fragmented, life, and a predilection for a comprehensive, all-inclusive and meaningful life animated and dedicated to communal ethics and communal life. More specifically, the demand that was raised during the event was for justice; justice without qualifications for economic rationality, debt credibility, accountability to creditors, and so on. The world was reduced to some basic bipolar moral principles: The needy vs. the powerful; the many vs. the few; the oppressed vs. the oppressors. The world of bureaucratic politics and global complexities was rejected for the sake of clarity and the rediscovery of the pure essence of democracy. In those meetings "the people" was simplified to those rejecting the "memorandum" and with it the old corrupted universe of Greek politics and economic life, and above all, the passive social life that accompanied it. How can we theorize such developments?

This wish for the detachment from, and, simultaneously, reconstitution of civil life, or, better the transformation of civil to civic life altogether, resembles, mutatis mutandis, Weber's religious "acosmistic brotherliness", a virtuous community committed to the development of an organic and moral social life. In principle, while religious 
brotherliness, as described by Weber, rejects the world as it is, it does not flee from the world. It is "world-rejecting", but not "world-fleeing" as it urges people to stay in and work with the world. The basis of world-rejecting moral stand is "acosmistic love" (Liebesakosmismus) a concept that denotes a "direct feeling of communion with God" which can incline the believer toward "an objectless world-denying love" and moves "in the direction of universalistic brotherliness, which goes beyond all barriers of social association, often including that of one's own faith."”

Symonds and Pudsey (2006), in a thorough overview of the concept, summarize its meaning as follows: "First, it is universal in scope. It applies to all human beings as sufferers. Second, it maintains a personal or ethical appreciation of the suffering of the other, emphasizing the face-to-face nature of care. Third, it is in tension with the orders of this world. As a consequence, it rejects this world as imperfect, thus becoming to a great extent world-denying or acosmic (see Bellah (1999) for an extended discussion of the meaning of "acosmism"). Under this acosmic orientation, only the suffering of other human beings is deemed important in this world. Finally, it is uncompromising in its dealing with the world. It refuses to accept any other value position as valid or worthwhile, and in this sense operates as an ethic of ultimate ends or 'convictions' (Gesinnungsethik)." (Symonds and Pudsey 2006:135-136)

Bellah's comment on the acosmistic, world-denial, love of Jesus to the world is suggestive:

For Jesus, whose attitude Weber characterizes as "an absolute indifference to the world" (1978:633), love of neighbor is inextricably linked with love of God. What Jesus calls "the greatest and first commandment" is the love of God, and the second is the love of neighbor (Mt. 22.37-40). And Jesus drastically extends the notion of neighbor, as Weber noted, to the stranger and the alien, as in the Parable of the Good Samaritan (Lk. 10.25-37), and even to the enemy as in the Sermon on the Mount: "Love your enemies and pray for those who persecute you" (Mt. 5.44). ${ }^{8}$

This might sound parochial - as belonging to a past era of pre-modern religiosity. Yet, the basic cognitive framework that the concept introduces, that is, the rejection of the world in its complexity as it stands in a given moment in time, the belief in the power of the suffering communitas is not restricted by time or history; thus, Weber's hope that the acosmistic love might survive the iron cage of modernity in the form of social democracy. ${ }^{9}$ Yet, at the same time Weber was pessimistic about this prospect as the radical ethics of brotherliness is squarely at odds with the political, economic, aesthetic, intellectual and erotic value spheres. As these spheres become rationalize, they confront head on the religion of brotherliness. In the economic sphere it is the "interest struggles of men in the market" that antagonizes acosmistic love; in the political sphere

${ }^{7}$ Weber (1946:330) quoted in R. Bellah, "Max Weber and World-Denying Love: A Look at the Historical Sociology of Religion" Journal of the American Academy of Religion, 67 (2): 1999, 277-304.

${ }^{8}$ R. Bellah, op.cit.

${ }^{9}$ Max Weber (1947: 545-546), in Bellah, ibid. 
is coercion. In the intellectual sphere it is the disenchantment intellectual knowledge produces. In the aesthetic sphere it is the form that becomes an object of adoration independent of content. As for the erotic sphere, "the more sublimated sexuality is, and the more principled and relentlessly consistent the salvation ethic of brotherliness is, the sharper is the tension between sex and religion". ${ }^{10}$ Each and every sphere denies the ethic of brotherliness which lies in the heart of salvation religions. This basic incompatibility between acosmistic love and modernity, or modern differentiation, rationalization and bureaucratization makes it an unstable entity.

However, I would argue, in cultures with a strong (pre-modern) tradition in it, the urge to experience acosmistic love, even as a transitory event, is strong. This is the case of the Syntagma Square movement and its demands for "direct democracy".

Selective affinity between radical egalitarianism and acosmistic love is obvious, but it becomes particularly strong in the Greek case whereas acosmistic love appears strong in religious social ethics (Makrides 2013). The Orthodox-theological imperative of experiencing emotionally rather than comprehending rationally the divine presence, the ecclesiastical congregation as a mystical union of believers, the collapse of linear time in sacerdotal events, in our secular era become the foundations for public protests to become experiences with transcendental qualitiy. ${ }^{11}$ In Greece the ideology of republican organic ethics and the Jacobin spirit become meaningful precisely through the deep cultural-religious patterns and collective representations and images of acosmistic love and the power of emotions as living religious experience (Marangudakis 2013). In a nutshell, republicanism is understood as a secular version of the undifferentiated and mystical Johannine love which must constitute the heart of communal life and of individual salvation. More important, this acosmistic love, even in its original, Orthodox religious version, is not ideologically blind, but in fact it is suspicious (to say the least) of modern liberalism and the West. It rejects, above all, the politics of power and capitalism as soul destroying forces ${ }^{12}$, and it is wary of social differentiation since in a differentiated society of multiple formal rationalities the republican hypergood, the "moral community", is fragmented, and the civic public citizen is diluted and dissolved into a civil private actor; no common good can be achieved in a civil society of privatized individuals (Selingman, 1995: 210).

It is interesting to notice that, as the Orthodox acosmistic religiosity takes two forms, the "defiant monk" and the "conformist priest", so was the Syntagma Square movement structured around two poles: One pole consisted of the anarchist community which combines "practicing republicanism" (i.e., part-time living in urban collectivist communities) with outbursts of ritualistic violence (e.g., orchestrated violent clashes with the police), while the other one consisted of humanitarians which combines

${ }^{10}$ Weber (1946:343), in Bellah, ibid.

${ }^{11}$ For the psychological effects of emotive religious experience see Whitehouse (2004); for the emotive character of the Orthodox faith see Marangudakis (2013).

${ }^{12}$ For a large-scale overview of Greek citizenship see Mouzelis (1995). For the conflation of the religious and the secular identity in Greece since 1974 see Marangudakis (2015). 
participation in republican meetings and protest rallies with philanthropic acts (e.g. providing for the poor and homeless, working in social pharmacies and food-shops, supporting NGO actions, participating in neighborhood meetings and cultural events). It is easy to understand such subdivisions as resulting from social structures and the position the individual holds in the social division of labor: Physicians would rather prefer to offer their services to a social clinic rather than throw petrol bombs at the Syntagma Square. Yet, social division of labor could not explain the justification offered by the professional or, for this matter, of any volunteer who explains his/her action in the framework of direct democracy and the conjoined rejection of the failed system of representative democracy. What these people do is not just to offer a hand to the people in need in a moment of severe crisis, but to do so as part of a republican ethical life. To trace the roots of mystical republicanism to religious sources we need to remind ourselves that Eastern religion is not Oriental, and not world-fleeing. In its own mystical framework it stresses the role of the believer as alleviator of human pain through acts of mercy and philanthropy, as social responsibility, a synergy of humans and God (Makrides, 2005). Since both Christian charity and social responsibility are seen through the lenses of mystical Johannine, acosmistic, love and emotive surrender of the intellect to the emptied self, neither of them is methodical (Hanganu, 2010). Yet, in this unmethodical form, philanthropy is highly effective in moments of crisis such as the one Greece faces right now. The drive to charity, in conjunction to the significance of in-worldly synergy of social action, in the framework of secular modernity becomes not only a fight against poverty but also a fight against the causes of poverty as well: injustice, greed, and selfishness. In the framework of the republican ideal of organic civic ethics, it becomes a fight against alienation, isolation, and privatization. Johannine mystical love becomes the republican undifferentiated organic community of fully committed citizens, and the congregation where you meet strangers for "the first time" and "you open your heart" and discover how "much in common" you have, and how much "you share with each other". The mystical community of believers in Christ becomes the neighborhood political meetings, the Syntagma Square directdemocracy happenings, or the social media networks that transcend space, and with it, republicanism itself turning it in to universal community.

Stelios Ramfos' analysis of the Greek psyche captures in ideal-type terms the psychological condition of a frustrated mystic remarkably well (Ramfos, 2011). He describes it as a "stretched-out will", a burning desire and an endless expectation without any wish to turn it into a practical project. Instead, it remains "an ocean of emotions unescorted by reason". The will remains unattached as it is oriented toward a featureless constitutive good instead of an inner conversation with the self; as it remains amorphous, the self gladly surrenders to emotiveness. This schismatic condition of social life corresponds to the religious meaning of the public sphere: the Orthodox faith, communal and mystical as it is, recognizes the public sphere as the space to express emotions of justice, but not as the space to put into practice civic responsibility. It cultivates a psychological state whereas social actors validate through their actions, performative or pro-active those might be, victory upon temptations of the fallen, corrupted, and unredeemable world. In this perspective, the performative 
acts of balaclava wearing, petrol-bomb throwing, anarchists are as religious as that of the humanitarians. They simply constitute the two sides of the same coin.

Yet, such a religious framework does not urge the actor to be methodical or socially responsible, since salvation is achieved not though social action, but through the emptying of the self and the crushing of individuality. This, combined with a rejection of physical, linear, time and the adoption of a flexible and reversible time perspective by the Orthodox Church, encourages a less-than-methodical structuration of the self. Thus, as its religious equivalent, "mystical republicanism" suffers from lack of methodical organization and therefore of the institutionalization of the lifeworld -a process that explains the sudden fall and virtual disappearance of the movement. Suspicious of organizational formalities and institutionalization processes that makes them, symbolically, part of "the system", and enamored with instances of spontaneous, undifferentiated, solidaristic, authentic, altruistic, and for these reasons virtuous communities, they experience the basic democratic code in a framework that insists to remaining elusive. Thus, the republican actions remain fragmented and transitory; as soon as the crisis is over, or the passion subsides, these social actors return to less-thanmeaningful, less-than-moral, routine life. Private life and social-moral action remain two domains foreign to each other.

How close is the model of contemporary practitioner of direct democracy with the republican citizen of classical Athens? Not close at all. For starters, there was no axialage dissociation of the immanent and the transcendental domains to trigger a project of institutional transformation. Instead, the Greek lived in a totally immanent world permanently volatile and unpredictable. I explain: His cosmological and ontological conceptions were shaped by the idea of Chaos (Xóos). For Hesiod (Theogony, 116) the sum of all beings (gods, humans, "things", "phenomena" and "forces") is born out of chaos, i.e., out of nothingness and of void ( $\alpha$ iv $\omega$ ), and thus, it should not to be confused with the later concept of generalized confusion. Yet, in Theogony there exists a final place, or a final depth, an inversion of the world, where Chaos is disorder; Hesiod calls it Tartaros (717-720, 722-723, 724-730, 731-735). The roots of this world -"of the earth and the barren sea"- come out of this huge vessel whose "mouth" is bound by a "triple night". The roots of the world (i.e., cosmos, order), its "other face" is this monstrous place. Only in this part of being, where we stand and live, reigns -for the moment- Zeus; it is only his presence that turns chaos into order and beauty (interchangeably, cosmos).

The world is not anthropocentric; it is not made for the humans and it does not "care" for them. There is no transcendental entity to be concerned with the human race, and certainly no entity to "love" them. The gods become involved with humans only when someone harms or offends them. And then, they are not all-mighty. Above them there is irrational and formless Fate (Moi $\rho \alpha)$ and it is she who first brought forward Ouranos, then Kronos, and then Zeus. Prometheus, in Aeschylus' version, warns Zeus:

A very solemn piece of insolence

Spoken like an underling of the Gods! Ye are young! Ye are young! New come to power and ye suppose 


\author{
Your towered citadel Calamity \\ Can never enter! Ah, and have not \\ Seen from those pinnacles a two-fold fall \\ Of tyrants? And the third, who his brief "now" \\ Of lordship arrogates, I shall see yet
}

(Prometheus Bound, 955-959).

At list until the end of the fifth century, there is no conception of life after death, and if there is, it is not "life" as we know it, but only an echo of it. This is clearly stated in Odyssey when Odysseus meats the shadow of Achilles in Hades. There Achilles' shadow tells Odysseus:

'Say not a word,' he answered, 'in death's favour; I would rather be a paid servant in a poor man's house and be above ground than king of kings among the dead' (Rhapsody 11/ $\lambda$, 488).

This pattern of existence could recognize birth and decay, return to chaos, and potentially, rebirth out of chaos. It could not conceptualize an ideal society as a political project emerging out of ontological and cosmological principles. Absence of a meaningful source of existence, of any comprehensive transcendentalism, meant absence of any conception of an ideal world being guaranteed by such a supreme entity or principle. It inspired an in-worldly perspective according to which man alone is responsible for his fate; anything else, anything above us, or below us, need not concern us. No prophets, no messiahs, no destiny is available to provide higher meaning; only the intellect of regular human beings. Chaos is already inside us in the form of hubris, i.e. our ignorance and inability to recognize the limits of our action. Tragedy warns humans of the danger of hubris whenever we cross the line of routine social life seeking truth; it reminds the Athenian citizen that there are limits unknown to the social actor beforehand; and that he is responsible for any calamity that finds him in his quest. Mostly, that it is up to him to discover his limits and avoid hubris. The Greek preoccupation with naturalism derives from the awareness of the feebleness of existence: It is only through the understanding of the abstract realities of nature that we will find the bearings to conceptualize the proper institutions for free citizens (Marangudakis, 2006). Thus, while the modern republican wishes to materialize some transcendental truth to "build the city of God", the ancient Athenian republican wished to realign himself with the bearings of nature, not in an effort to fulfill his destiny, but out of dignity for himself. It was his choice to find truth without the hope of salvation; for this reason, it was a tragic truth; he accepted it.

And instead of relying on a universal brotherhood, the Athenian citizen was molded in the furnace of the intense community life. He was directly responsible for the running of his household, his immediate demos, and as a hoplite, for the defense of the city of Athens. It was through these arduous tasks that his worldview was shaped. These all resulted in a definite attitude toward the "state" and his fellow citizens, the celebrated civic virtue that was the common feature of all republican city-states' citizens of the 
ancient world. He was the carrier of practical action attached to routine issues that concerned the demos, the Boule and the Ecclesia. Emotionally he was attached to his family, his hoplite companions, and his Athenian community as he experienced it though festivals, rituals, and common concerns. In other words, his social relationships were "communal" (Vergemeinschaftung) as they were based primarily on face-to-face affectual and traditional bonds; the political bonds (the various institutional roles) were following, and thus they were embedded on strong foundations.

Does this mean that the difference between the ancient republican citizen and the contemporary one lies in the construction of the "community"? To outline an answer, we should go back to Weber's own theoretical analysis: Acosmistic brotherliness is at odds with the political, economic, aesthetic, intellectual and erotic value spheres. As these spheres become rationalize, they confront head on the religion of brotherliness. In the economic sphere it is the "interest struggles of men in the market" that antagonizes acosmistic love; in the political sphere is coercion. In the intellectual sphere it is the disenchantment intellectual knowledge produces. In the aesthetic sphere it is the form that becomes an object of adoration independent of content. As for the erotic sphere, "the more sublimated sexuality is, and the more principled and relentlessly consistent the salvation ethic of brotherliness is, the sharper is the tension between sex and religion". ${ }^{13}$ Each and every sphere denies the ethic of brotherliness which lies in the heart of salvation religions.

In other words, certain crucial aspects of modernity restrict the wish for brotherliness to the point of altering its own essence. The analysis of the Syntagma Square movement suggests the presence of these restrictions (economic hardship, political disfranchising, etc.) as well as the atomistic character of participation (strangers meeting strangers) allowing us to reason that it does not constitute a holistic community, or what Victor Turner would call a communitas, i.e. a homogenous totality striped of social differentiations (Turner 1974: 273-74). But they neither constitute "associative social relationships"14 (Vergesellschaftung), the other pole in Weber's typology of social relations, since the participants' intentional goal was the establishment of new social relations based on values rather than interests. The Syntagma Square, direct-democracy, movement was factually a protest movement that wished to be a reform movement. It failed due to the overwhelming tensions with other value spheres. It was made primarily of people enraged by the collapse of their world around them as well as by the collapse of their own well-being, who were engulfed by a desire to erase everything and start from scratch, or to use Ramfos' expression, “....with a burning desire and an endless expectation without any wish to turn it into a practical project; an ocean of emotions unescorted by reason". The participants wished to bring in life a virtuous community of equals, but lack of methodical planning and structural pressures from the outside

${ }^{13}$ Weber (1946:343), in Bellah (1999)

14 "Rationally motivated adjustment of interests or a similarly motivated agreement, whether the basis of rational judgment be absolute values or reasons of expediency" (Weber, 1978, 4041). 
brought it to an end. Its collapse, a few months later, in the hot days of the summer of 2013, when most of the participants had left Athens for summer vacations and the Square was in a sorry condition, ended with a wimp. A few voices were raised to protest the cleaning up of the Square and the removal of the semi-permanent structures that the Greek indignados had installed, but that was all. Eventually it was absorbed by more institutionalized organizations, such as the anti-memorandum parties SYRIZA (lower Syntagma Square) and Golden Dawn (upper Syntagma Square).

Thus we arrive at the core of the issue at hand: trust. While the ancients presumed a certain level of dependence on each other, of common destiny and communal pride, the modern version, as it unfolded in Syntagma Square as well as in other central Squares in all major Greek cities revealed not just civic, but civil mistrust. While it is quite understandable that the participants rejected the state as unable to provide the basic collective goods that it was expected from it, it is not so the deep mistrust toward those who were not agreeing with the basic contours of their protest against the troika and the memorandum with Greece's international partners. This could also be understood as a consequence of the demands of the movement, but the fact that fellow citizens were rejected out of hand and stigmatized as traitors, suggests a certain level of incivility. If for the ancients democracy was conceptualized as the rule of laws rather than of persons and their wishes, then it is quite possible the Square Movement would be recognized by an ancient Athenian as being closer to a factional political movement rather than to democratic practice.

Direct democracy, as it was practiced originally, guaranteed a sense of personal responsibility and the legitimation of the wider, representative, democratic regime. This combination remains valid even today. In this equation direct democracy is not a consubstantial part of a homogenous democratic continuum. Instead, direct democracy is substantially different from representative institutions and it could offer something that representative democratic institutions cannot: the participation of every member of the community as equal, as a fellow brother and sister, rather than as a predetermined, biased, member of the government or of the opposition; in other words, to become a premise of modern parrhesia, and the trust it cultivates. A reason that the Syntagma Square movement failed was that parrhesia and trust was saved only for those with similar opinions. Instead of reflecting an acosmistic brotherhood of sufferers, or a communitas, it came to reflect de Tocqueville's "tyranny of the majority". A direct democracy process based on resemblance rather than on inclusion collides head-on with the principles of representative democracy. It is the perennial problem of modern Greek democracy.

\section{References}

Adkins, A. W. H. (1972): Moral Values and Political Behaviour in Ancient Greece: From Homer to the End of the Fifth Century, London, Chatto and Windus.

Bellah R. (1999): "Max Weber and World-Denying Love: A Look at the Historical Sociology of Religion", Journal of the American Academy of Religion, 67 (2), pp. 277-304. 
Foucault, M. (2001): Fearless Speech, in Joseph Pearson (ed.), Los Angeles, Semiotext(e).

Hanganu, G. (2010): 'Eastern Christianities and religious objects: personal and material biographies entangled' in Chris Hann and Hermann Goltz, editors, Eastern Christians in Anthropological Perspective, Berkeley, University of California Press, pp. 33-55.

Hansen, M. H. (1991): The Athenian Democracy in the Age of Demosthenes, Blackwell, Oxford.

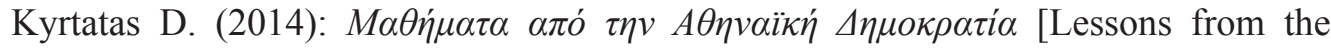

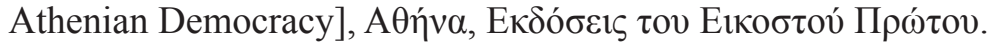

Leontidou L. (2012): Athens in the Mediterranean 'movement of the piazzas'. Spontaneity in material and virtual public spaces, City: analysis of urban trends, culture, theory, policy, action, 16, pp. 299-312.

Marangudakis, M. (forthcoming): From Salvation to Purgatory: Cultural Codes and Moral Orders in Greece, Propompos, Athens.

Marangudakis, M. (2013): "The Self in Eastern Orthodoxy", International Political Anthropology, (6)1, pp. 3-16.

Marangudakis, M. (2015): "Civil Religion in Greece; a Study in the Theory of Multiple Modernities", Protosociology, 32, pp. 187-215.

Marangudakis, M., K. Rontos and M. Xenitidou (2013): "State Crisis and Civil Consciousness in Greece", GreeSE: Hellenic Observatory Papers on Greece and Southeast Europe, 77.

Marangudakis, M. (2006): 'Social Sources and Environmental Consequences of Axial Thinking: Mesopotamia, China and Greece in Comparative Perspective', European Journal of Sociology, 1, pp. 59-92.

Makrides, V. (2005): "Orthodox Christianity, Rationalization, Modernization: A Reassessment" in V. Roudometof, A. Agadjanian, and J. Pankhurst, editors, Eastern Orthodoxy in a Global Age, Oxford: Rowman \& Littlefield Publishers, pp. 179-210

Makrides, V. (2013): "Why does the Orthodox Church Lack Systematic Social Teaching?" Skepsis, 23, pp. 281-312.

Mouzelis N. (1995): "Modernity, Late Development and Civil Society" in John Hall (ed.) Civil Society; Theory, History, Comparison, Polity Press, London.

Ramfos, S. (2011): Yearning for the One; Chapters in the Inner Life of the Greeks, Brookline Mass., Holy Cross Orthodox Press, 2011.

Seligman, A. B. (1995): "Animadversions upon Civil Society and Civic Virtue in the Last Decade of the Twentieth Century", in J. A. Hall (ed.), Civil Society: Theory, History, Comparison, Cambridge, Polity Press

Symonds, M. and J. Pudsey (2006): "The forms of brotherly love in Max Weber's Sociology of Religion", Sociological Theory, 24 (2), pp. 133-149.

Tsaliki L. (2012): The Greek 'Indignados': The Aganaktismeni as a case study of the 'new repertoire of collective action, Paper delivered at the "In/compatible publics: Publics in Crisis- Production, Regulation and Control of Publics" panel, Transmediale Media Art Festival, Berlin. (Available at www2.media.uoa.gr/people/tsaliki/wp-content/ uploads/2010/07/Tsaliki_The_Greek_Indignados.pdf - accessed on 20/12/2013). 
Turner V. (1974): Dramas, Fields, and Metaphors: Symbolic Action in Human Society, Cornell University Press.

Wallace, R. W. (2002): "The Power to Speak — and not to listen - in Ancient Athens", in Sluiter, Ineke; Rosen, Ralph Mark (eds.), Free Speech in Classical Antiquity, Brill.

Weber, M. (1978): Economy and Society, Guenther Roth and Claus Witrich (eds.), Berkeley, University of California Press.

Weber, M. (1947/1921): Collected Essays on the Sociology of Religion Vol.I [Gesammelte Aufsätze zur Religionssoziologie. Tübingen: J. C. B. Mohr.

Whitehouse, H. (2004): Modes of Religiosity: A Cognitive Theory of Religious Transmission, London, Altamira Press. 